JCH (Jurnal Cendekia Hukum)

Volume 6 Nomor 1, September 2020

e-ISSN: 2580-1678 dan ISSN: 2355-4657

Open Access: http://e-jurnal.stih-pm.ac.id/index.php/cendekeahukum/index

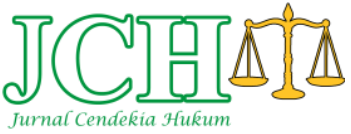

\title{
EFEKTIFITAS PERAN OMBUDSMAN REPUBLIK INDONESIA PERWAKILAN PROVINSI KEPULAUAN RIAU SEBAGAI LEMBAGA PENGAWAS PELAYANAN PUBLIK DI KOTA BATAM*
}

\author{
Winsherly Tan \\ Program Studi Hukum Universitas Internasional Batam \\ e-mail: winsherly@uib.ac.id
}

\begin{abstract}
It is hoped that the presence of the Ombudsman of the Republic of Indonesia is able to serve the delivery of public services for the realization of state and government administration that is effective and efficient, honest, clean, open, and free from corruption, collusion and nepotism. This purpose is to analyze the problem factors and provide solutions to solve the problems of investigating the problems of the Ombudsman of the Republic of Indonesia Representatives of the Riau Islands Province in completing reports and preventing maladministration in Batam City. Legal Research Methods The results of observations, interviews and questionnaires as the main data source and literature study as a source of supporting data showed that the supervision of the Ombudsman of the Republic of Indonesia Representatives of the Riau Islands Province in Batam City has not been effective. The problem factors for the Ombudsman of the Republic of Indonesia Representatives of the Riau Islands Province in public services in Batam City, namely less than the budget, absence of reports, legal uncertainty, lack of support from public service providers, Ombudsman coordination and collaboration with public service providers, and public awareness. Based on these problems, the suggestion from the researcher is a recommendation so that the duties and functions of the Ombudsman run more effectively in accordance with the mandate of the Law, namely: with the revision of the UUORI and implementing regulations for legal certainty, increasing the budget and quality of the Indonesian Ombudsman HR Representatives of the Riau Islands Province , collaborating with public service providers.
\end{abstract}

Keywords: Ombudsman; Maladministration; Public Service; Effectiveness; Batam City.

\begin{abstract}
Abstrak
Kehadiran Ombudsman Republik Indonesia diharapkan mampu untuk mengawasi penyelenggaran pelayanan publik demi terwujudnya penyelenggaraan negara dan pemerintahan yang efektif dan efisien, jujur, bersih, terbuka, serta bebas dari korupsi, kolusi dan nepotisme. Tujuan penelitian ini adalah untuk menganalisa faktor-faktor permasalahan serta memberikan solusi untuk mengatasi permasalahan-permasalahan Ombudsman Republik Indonesia Perwakilan Provinsi Kepulauan Riau dalam menyelesaikan laporan dan upaya pencegahan maladministrasi di Kota Batam. Metode Penelitian Hukum Empiris melalui hasil observasi, wawancara dan kuesioner sebagai sumber data utama serta studi pustaka sebagai sumber data pendukung maka diperoleh hasil penelitian bahwa pengawasan Ombudsman Republik Indonesia Perwakilan Provinsi Kepulauan Riau di Kota Batam belum berjalan efektif. Faktor permasalahan Ombudsman Republik Indonesia Perwakilan Provinsi Kepulauan Riau dalam mengawasi pelayanan publik di Kota Batam, yaitu kurangnya SDM, kurangnya anggaran, tidak adanya identifikasi laporan, ketidakpastian hukum, kurangnya dukungan penyelenggara pelayanan publik, kurangnya kordinasi dan kerjasama Ombudsman dengan penyelenggara pelayanan publik, serta kurangnya kesadaran masyarakat. Berdasarkan permasalahan-permasalahan tersebut, maka saran dari peneliti sebagai rekomendasi agar tugas dan fungsi Ombudsman berjalan lebih efektif sesuai dengan amanat Undang-Undang, yaitu: dengan revisi UUORI dan peraturan pelaksana demi kepastian hukum, menambah anggaran
\end{abstract}

\footnotetext{
* Naskah diterima: 18 Agustus 2020, direvisi: 24 September 2020, disetujui untuk terbit: 28 September 2020 Doi: $10.3376 /$ jch.v6i1.284
} 
dan kualitas SDM Ombudsman RI Perwakilan Provinsi Kepulauan Riau, mengadakan kerjasama dengan penyelenggara pelayanan publik.

Kata Kunci: Ombudsman; Maladministrasi; Pelayanan Publik; Efektivitas; Kota Batam.

PENDAHULUAN

"Negara Indonesia berdasar atas Hukum (Rechtsstaat) tidak berdasar atas kekuasaan belaka (Machtsstaat)". (Aidul, 2012) Menurut Padmo dalam bukunya "Membudayakan UUD 1945", bahwa Telah tegas tercantum dalam konstitusi sebagai hukum tertinggi (the highest law) bahwa Indonesia adalah negara hukum. (Atika, 2020)

Konstitusi mendelegasikan bahwa tujuan didirikannya NKRI, ialah guna meningkatkan kesejahteraan umum serta mencerdaskan kehidupan bangsa dan untuk mewujudkannya, Negara wajib memenuhi hajat hidup orang banyak melalui penyelenggaraan pelayanan publik berkualitas yang mendorong terpenuhinya keperluan dasar serta hakhak asasi setiap penduduk masyarakat berupa pelayanan jasa, barang dan administrasi. Rumusan serupa juga tampak pada pasal 27 UUD 1945, yang mana seluruh penduduk masyarakat memiliki hak atas pencaharian dan nafkah yang memadai guna kemanusiaan, serta pasal 31 yang berisikan mengenai pelayanan edukasi, pasal 33 yang mana pelayanan publik terhadap sumber daya alam haruslah digunakan terhadap sebesar-besarnya kemakmuran rakyat, berikut pasal 34 yang menyatakan bahwa fakir miskin juga anak-anak telantar diurus oleh Negara. (Ombudsman, 2018)

Dalam rangka mendistribusikan kesejahteraan tersebut, maka negara menyelenggarakan pelayanan publik kepada seluruh masyarakat. Menurut Undang-Undang Nomor 25 tahun 2009 tentang Pelayanan Publik.

Pelayanan publik hampir secara otomatis membentuk citra (image) tentang kinerja birokrasi, karena kebijakan Negara yang menyangkut pelayanan publik tidak lepas dari birokrasi. Sehubungan dengan itu, kinerja birokrasi secara langsung berkaitan dengan masalah kualitas pelayanan yang diberikan oleh aparatur. (Rudi, 2012)

Dalam rangka memajukan kualitas berikut memberikan jaminan pelayanan publik serta guna melindungi tiap warga negara juga penduduk dari penyalahgunaan kekuasaan dalam suatu penyelenggaraan pelayanan publik, maka Indonesia telah membentuk sebuah lembaga pengawas penyelenggaraan pelayanan publik melalui UndangUndang Nomor 37 Tahun 2008 tentang Ombudsman Republik Indonesia.

Kehadiran Ombudsman Republik Indonesia merupakan lembaga negara yang memiliki tugas dan kewenangan dalam menjalankan fungsi pengawasan pada penyelenggaraan pelayanan publik baik pada lembaga birokrasi, institusi pendidikan, Badan Usaha Miliki Negara serta Badan Usaha Milik Daerah dan Badan Hukum Miliki Negera serta badan usaha swasta atau perorangan. (Sukur, 2020) 
Winsherly Tan: Efektifitas Peran Ombudsman Republik Indonesia Perwakilan...

Adapun tujuan pembentukan Komisi Ombudsman Nasional tersebut, adalah untuk membantu menciptakan dan atau mengembangkan kondisi yang kondusif dalam melaksanakan pemberantasan Korupsi, Kolusi, dan Nepotisme melalui peran serta masyarakat. Selain itu, untuk meningkatkan perlindungan hak-hak masyarakat agar memperoleh pelayanan umum, keadilan, dan kesejahteraan secara lebih baik. (Imron, 2018)

Ombudsman RI yang dulunya disebut sebagai Komisi Ombudsman Nasional (atau yang selanjutnya disebut $\mathrm{KON}$ ) berdasarkan suatu Keputusan Presiden pada tahun 2000, dibentuk berdasarkan maksud untuk mencapai tercipta serta berkembangnya suatu keadaan yang kondusif pada pelaksanaan tugas pemberantasan KKN, peningkatan perlindungan atas hak-hak warga negara supaya mendapat suatu pelayanan publik, serta terciptanya suatu kesejahteraan dan keadilan bagi setiap masyarakat. Kesejahteraan rakyat merupakan salah satu tujuan bernegara. (Darmini, 2019)

Ketika belum didirikannya KON, masyarakat dalam mengadukan suatu pelayanan publik menyampaikan aduannya tersebut hanya pada Instansi terlapor dan penanganannya juga acap kali dilaksanakan oleh pejabat terlapor tesebut sehingga oleh karenanya masyarakat belum mendapatkan suatu perlindungan yang patut. Disamping itu, penyelesaian perkara atas permasalahan pelayanan publik selama ini hanya melalui pengadilan dengan cara gugatan. Upaya itu tentu membutuhkan waktu penyelesaian perkara yang memakan waktu lama serta biaya yang banyak. Oleh karena itu, dibutuhkan suatu lembaga yang bersifat mandiri yang dalam hal ini disebut Ombudsman guna menyelesaikan aduan dan/atau laporan atas pelanggaran pelayanan publik secara mudah serta tanpa adanya pungutan biaya. Ombudsman tersebut bersifat bebas dari campur tangan kekuasaan lainnya guna melaksanakan fungsi dan tanggungjawabnya.

Maladministrasi sebagaimana tertuang dalam pasal 1 angka 3 , berarti: "perilaku atau perbuatan melawan hukum, melampaui wewenang, menggunakan wewenang untuk tujuan lain dari yang menjadi tujuan wewenang tersebut, termasuk kelalaian atau pengabaian kewajiban hukum dalam penyelenggaraan pelayanan publik yang dilakukan oleh Penyelenggara Negara dan pemerintahan yang menimbulkan kerugian materiil dan/atau immateriil bagi masyarakat dan orang perseorangan".

Guna melaksanakan fungsi dan tanggungjawabnya, Ombudsman dapat mendirikan Perwakilan Ombudsman di wilayah Provinsi maupun Kota/Kabupaten. Pada provinsi Kepulauan Riau, Ombudsman Perwakilan telah dibentuk dari tahun 2012 lalu. (Kartika, 2018) Walaupun sudah berdiri sejak tahun 2000, ternyata mayoritas masyarakat Indonesia masih belum mengenal bahkan tak mengetahui perihal adanya Ombudsman sebagai lembaga negara pengawas pelayanan publik. (Fikri, 2018) Masyarakat juga tidak mengetahui 
perihal apa yang dimaksud dengan maladministrasi berikut bahwa suatu pelanggaran maladministrasi yang dilakukan oleh suatu penyelenggara pelayanan publik dapat dilaporkan kepada Ombudsman. (Fachri , 2018)

Di provinsi Kepulauan Riau, Ombudsman Republik Indonesia dianggap sebagai pengumpul kasus pelayanan publik yang seolah pengaduan dari masyarakat tidak ada yang ditindaklanjuti dan tidak ada hasil yang disampaikan ke pengadu ataupun masyarakat atas hasil dari pengaduan yang disampaikan tersebut. (Admin, 2018)

Selain itu, kompetensi pegawai pelayan publik di Pemerintah Provinsi Kepulauan Riau dinilai masih rendah. Hal itu diketahui dari hasil penelitian Ombudsman Republik Indonesia. Akibatnya wilayah provinsi Kepulauan Riau masuk dalam zona merah. Penelitian ini dilakukan di 22 Provinsi, 44 Kota dan 106 Kabupaten dan di publikasikan di Kantor Ombudsman Republik Indonesia di Jakarta pada Rabu, 22 Februari 2018. (Jun, 2018) Dari segi laporan yang diterima, Ombudsman Republik Indonesia Perwakilan Provinsi Kepri memperoleh sebanyak 155 laporan di tahun 2017, jumlah laporan ini bertambah apabila dibandingkan dengan tahun 2016 yang berjumlah 140 laporan. Terhadap jumlah laporan di provinsi Kepri tersebut, jumlah laporan terbanyak pada tahun 2017 bersumber dari Kota Batam yang menyumbang sebesar 129 laporan. (Messa, 2018)
Pelaksanaan pengawasan penyelenggaraan pelayanan publik yang dilakukan oleh Ombudsman Republik Indonesia diharapkan dapat mendukung terwujudnya pemerintahan yang baik (good governance). Konsep good governance telah menjadi kemauan politik dalam berbagai peraturan perundangundangan Negara Indonesia. Oleh karena itu Ardi Partadinata sebagaimana dikutip oleh H.A. Muin Fahmal menyatakan bahwa good governance sebagai norma pemerintahan adalah suatu sasaran yang akan dituju dan diwujudkan dalam pelaksanaan pemerintahan yang baik. (Solechan, 2018: 69)

Berdasarkan hal tersebut maka terdapat rumusan masalah dalam penelitian ini yaitu Pertama, Bagaimana Efektivitas Ombudsman Republik Indonesia Perwakilan Provinsi Kepulauan Riau sebagai Lembaga Pengawas Pelayanan Publik di Kota Batam ?. Kedua, Faktor apa sajakah yang menjadi permasalahan Lembaga Ombudsman Republik Indonesia Perwakilan Provinsi Kepulauan Riau dalam mengawasi pelayanan publik di Kota Batam ?

\section{METODE PENELITIAN}

Jenis penelitian data yang digunakan oleh penulis dalam menyusun penelitian tersebut yaitu penelitian yuridis-empiris (applied law research). (Peter, 2010). Jenis data yang digunakan penulis dalam penelitian tersebut yaitu berupa hukum yuridis empiris berupa data primer dan data sekunder. (Mukti, 2010: 153) Data primer adalah data yang diperoleh langsung dari sumbernya melalui 
Winsherly Tan: Efektifitas Peran Ombudsman Republik Indonesia Perwakilan...

wawancara terhadap narasumber yaitu Bapak Lagat Parroha Patar Siadari, S.E., M.H., selaku Kepala Perwakilan Ombudsman Provinsi Kepulauan Riau. Wawancara dilaksanakan selama 3 (tiga) kali, yakni pada: 17 Desember 2018, 20 Desember 2018, dan 21 Desember 2018 bertempat di Kantor Ombudsman RI Perwakilan Provinsi Kepulauan Riau. Data yang telah terkumpul dari penelitian tersebut akan dianalisa dengan metode kualitatif, artinya menganalisis keseluruhan dan diimplementasikan dengan menyusun data yang telah dikumpulkan secara sistematis dan menghasilkan sebuah kesimpulan.

HASIL DAN PEMBAHASAN
1. Pelaksanaan
Pengawasan
Pelayanan Publik di Kota Batam

\section{oleh Ombudsman Republik Indonesia Perwakilan Provinsi Kepulauan Riau.}

Prinsip utama pelayanan dalam paradigma Pelayanan Publik Baru yang harus diwujudkan agar pemerintah mampu memberikan pelayanan yang berkualitas, yaitu dengan Citizens Influence atau ukuran sejauh mana warga dapat mempengaruhi kualitas pelayanan yang mereka terima dari pemerintah. (Adhar, 2015) Kehadiran Ombudsman adalah untuk mengawasi pelayanan publik tersebut.

Namun, berdasarkan data yang diperoleh dari Ombudsman RI Perwakilan Provinsi Kepri diketahui bahwa jumlah laporan pada tahun 2018 adalah sebagai berikut:

\section{Gambar 1. Jumlah Pengaduan Berdasarkan Instansi Terlapor Tahun 2018 di Kepri}

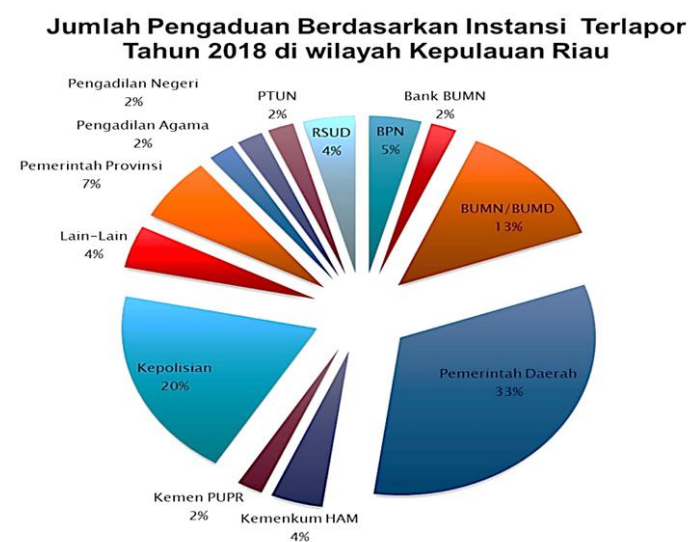

Melalui data statistik tersebut di atas bisa dilihat bahwa Instansi yang paling sering dilaporkan oleh masyarakat ialah Pemerintah Daerah (33\%), Kepolisian (20\%) disusul BUMN/BUMD (13\%).
Adapun jumlah laporan Ombudsman adalah sebanyak 146 laporan (2018), 155 laporan (2017) dan 140 laporan (2016) dengan jenis maladministrasi sebagai berikut:

Tabel 1. Informasi Statistik Dugaan Maladministrasi Tahun 2019

\begin{tabular}{clcc}
\hline No & & Aspek & Jumlah \\
\hline 1 & Berpihak & & 2 \\
2 & Diskriminasi & & 1
\end{tabular}


$3 \quad$ Penundaan Berlarut 42

4 Penyalahgunaan Kewenangan 4

$5 \quad$ Penyimpangan Prosedur 36

6 Permintaan imbalan uang, brang dan jasa 1

7 Tidak kompeten 4

8 Tidak memberikan pelayanan $\quad 54$

9 Tidak patut 2

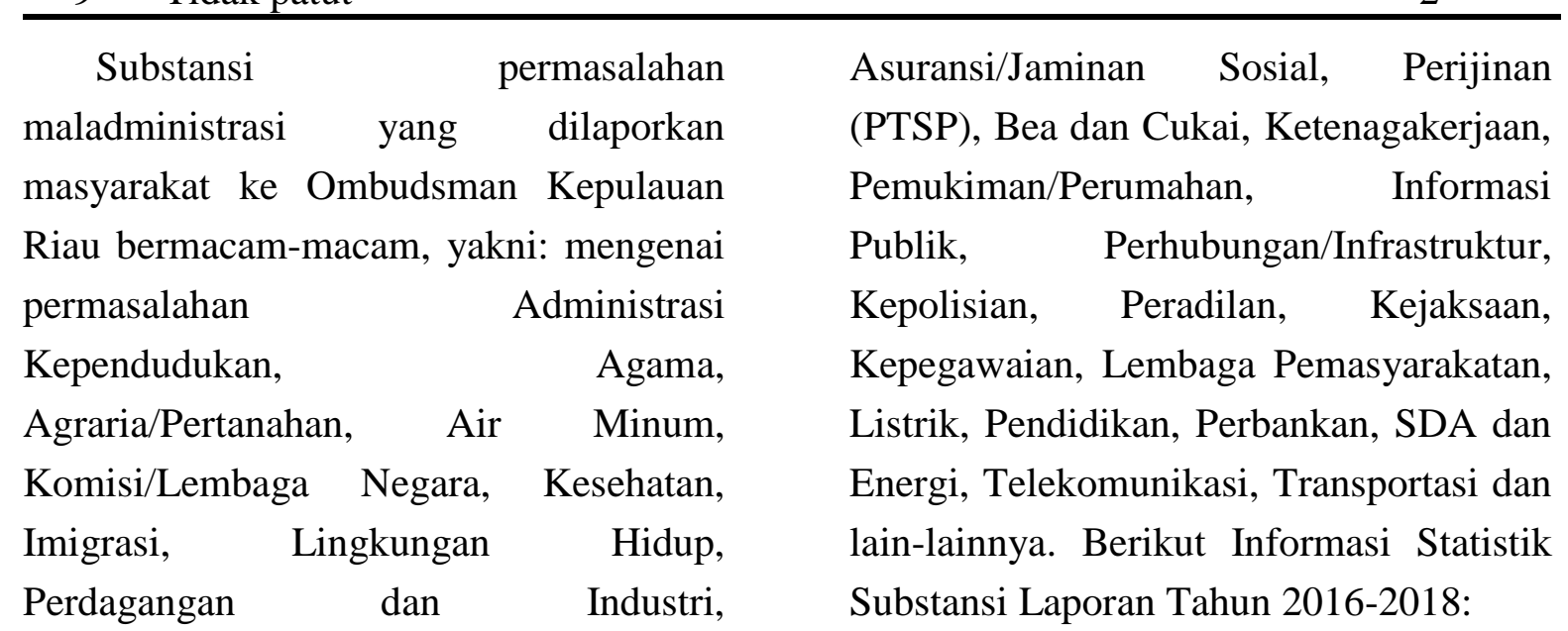

Tabel 2. Informasi Statistik Substansi Laporan Tahun 2016-2018

\begin{tabular}{|c|c|c|}
\hline No & $\begin{array}{ll}\text { Aspek } \\
\end{array}$ & Jumlah \\
\hline 1 & Administrasi Kependudukan & 9 \\
\hline 2 & Agraria/Pertanahan & 16 \\
\hline 3 & Air Minum & 6 \\
\hline 4 & Asuransi/Jaminan Sosial & 4 \\
\hline 5 & Bea dan Cukai & 3 \\
\hline 6 & Imigrasi & 1 \\
\hline 7 & Informasi Publik & 10 \\
\hline 8 & Kejaksaan & 3 \\
\hline 9 & Kepegawaian & 5 \\
\hline 10 & Kepolisian & 12 \\
\hline 11 & Kesehatan & 5 \\
\hline 12 & Ketenagakerjaan & 3 \\
\hline 13 & Lingkungan hidup & 6 \\
\hline 14 & Listrik & 1 \\
\hline 15 & Pajak & 8 \\
\hline 16 & Pemukiman & 4 \\
\hline 17 & Pendidikan & 13 \\
\hline 18 & Peradilan & 3 \\
\hline 19 & Perbankan & 3 \\
\hline 20 & Perhubungan & 14 \\
\hline 21 & Perijinan & 6 \\
\hline 22 & Perikanan & 1 \\
\hline
\end{tabular}

Selanjutnya, berikut ini pemaparan

Ombudsman Kepulauan Riau tahun 2012data Informasi Statistik Laporan 2018 (per Agustus) mengenai 
Winsherly Tan: Efektifitas Peran Ombudsman Republik Indonesia Perwakilan...

penyelesaian jumlah pengaduan atau dari Ombudsman Republik Indonesia laporan yang masuk ke Ombudsman Perwakilan Provinsi Kepulauan Riau:

setiap tahunnya yang Peneliti dapatkan

Tabel 3. Informasi Statistik Laporan Ombudsman Kepulauan Riau

(Tahun 2012-2018)

\begin{tabular}{|c|c|c|c|}
\hline No & Tahun & Proses & Selesai \\
\hline 1 & 2012 & & 5 \\
\hline 2 & 2013 & 18 & 54 \\
\hline 3 & 2014 & 127 & 55 \\
\hline 4 & 2015 & 59 & 51 \\
\hline 5 & 2016 & 115 & 25 \\
\hline 6 & 2017 & 142 & 13 \\
\hline 7 & 2018 & 22 & 42 \\
\hline
\end{tabular}

Melalui pemaparan data statistik di atas dapat diketahui bahwa total jumlah pengaduan Ombudsman Perwakilan Kepulauan Riau pada tahun 2012-2018 (per Agustus) ialah 728 laporan dengan total laporan selesai ialah sebanyak 483 laporan dan total laporan proses ialah sebanyak 245 laporan. Selanjutnya melalui hasil olah data, Peneliti memperoleh presentase penyelesaian laporan Ombudsman setiap tahunnya ialah sebesar $66,3 \%$ laporan. Sebaliknya jumlah laporan yang tidak diselesaikan atau proses penyelesaiannya dilanjutkan di tahun berikutnya ialah sebesar $33,7 \%$ laporan.

\section{Faktor-faktor yang menjadi permasalahan Lembaga \\ Ombudsman Republik Indonesia Perwakilan Provinsi Kepulauan Riau dalam mengawasi pelayanan publik di Kota Batam}

Pemerintahan di seluruh dunia pada saat ini menghadapi "tekanan" dari berbagai pihak untuk meningkatkan kualitas pelayanan publik dan meningkatkan partisipasi aktif dalam pemberian informasi bagi masyarakat serta dituntut untuk lebih efektif. (Erick, 2011: 21)

Pemerintah mempunyai peranan penting untuk menyediakan layanan publik yang prima bagi semua penduduknya sesuai yang telah diamanatkan dalam Undang-Undang. (Yayat, 2017) Pelayanan pubik masih menjadi masalah dalam birokrasi di Indonesia, banyak faktor dan ragam yang menyebabkan hal tersebut menjadi momok di mata masyarakat. Kebutuhan masyarakat di era milleneal saat ini cenderung besar dengan keinginan untuk mendapatkan pelayanan yang cepat dan tepat. (Robi, 2016)

Pelayanan publik kepada masyarakat adalah salah satu tugas atau fungsi penting pemerintah dalam menyelenggarakan tugas-tugas pemerintahannya. ( Hamdani, 2015)

Adanya penerapan kebijakan otonomi daerah di Indonesia menimbulkan harapan besar bagi masyarakat, terutama dalam hal peningkatan pelayanan publik. 
Berkembangnya tuntutan masyarakat sebagai indikasi peran yang semakin kritis menginginkan adanya birokrasi dalam organisasi pemerintahan yang profesional, khususnya dalam pelaksanaan pelayanan publik yang berkualitas. (Ni Luh, 2016)

Dari hasil analisa dan fakta di lapangan, terdapat berbagai faktor yang memicu ketidakefektifan Ombudsman Republik Indonesia Perwakilan Provinsi Kepulauan Riau dalam mengawasi Pelayanan Publik di Kota Batam, yakni:

\section{a. Faktor Internal}

1) Kurangnya Sumber Daya Manusia (SDM)

Sumber Daya Manusia adalah salah satu faktor yang sangat penting yang tidak bisa dilepaskan dari sebuah Lembaga negara dalam menjalankan tugas dan fungsinya.

Berdasarkan hasil penelitian terdapat beberapa permasalahan Ombudsman Perwakilan Kepulauan Riau dalam melaksanakan tugasnya sebagai lembaga pengawas pelayanan publik di Kota Batam. Permasalahan tersebut diantaranya: Kurangnya Jumlah Asisten, Kurangnya Kemampuan Asisten, Kurangnya Kekompakan Tim serta Kurangnya Pelatihan.

Saat ini Ombudsman Perwakilan Kepulauan Riau hanya memiliki 8 (delapan) orang Asisten dalam melaksanakan tugasnya. Jumlah Asisten tersebut di atas tentu tidak sebanding mengingat luasnya lingkup geografis provinsi Kepulauan Riau serta kompleksnya tanggungjawab Asisten dalam menyelesaikan laporan maladministrasi yang sangat beragam. Kelompok keasistenan sendiri terbagi 3 (tiga) bidang, yakni: Bidang Pencegahan yang terdiri dari 2 (dua) Asisten, Bidang Penerimaan dan Verifikasi Laporan yang terdiri dari 2 (dua) orang Asisten, serta Bidang Pemeriksaan Laporan yang terdiri dari 4 (empat) orang Asisten.

Menurut Kepala Perwakilan Ombudsman Kepulauan Riau, idealnya terdapat minimal 11 (sebelas) jumlah Asisten di Ombudsman Perwakilan Kepulauan Riau. Selain itu permasalahan berikutnya adalah kurangnya Kompetensi atau Kapabilitas dari Asisten yang bertugas di Ombudsman Kepulauan Riau.

2) Kurangnya Anggaran

Kurangnya anggaran di Ombudsman Perwakilan Kepulauan Riau menyebabkan kurangnya Fasilitas dan Sarana serta tidak maksimalnya Ombudsman Kepri dalam menjalankan fungsinya baik dalam penyelesaian laporan maupun upaya pencegahan maladministrasi.

Dalam bentuk sarana dan fasilitas, saat ini Ombudsman Kepri membutuhkan anggaran untuk membeli keperluan operasional seperti Kendaraan Tambahan serta Fasilitas pendukung seperti Kamera, Alat Perekam, Infokus Portable, Spy Cam, Laptop dan Printer Portable. Anggaran juga sangat diperlukan agar tugas pencegahan seperti misalnya sosialisasi dapat dilaksanakan di seluruh wilayah Provinsi Kepulauan Riau.

3) Tidak Adanya Identifikasi Laporan 
Winsherly Tan: Efektifitas Peran Ombudsman Republik Indonesia Perwakilan...

Mengingat beragamnya jenis substansi laporan yang harus Ombudsman selesaikan, dibutuhkan adanya identifikasi laporan.

Adanya identifikasi laporan yang dimaksudkan yakni pembagian kategori laporan masyarakat menjadi 3 (tiga) bagian, yaitu: Ringan, Sedang, dan Berat. Contoh bentuk dari laporan yang bersifat ringan seperti Laporan Administrasi Kependudukan seperti mengenai permasalahan KTP dan bentuk dari laporan yang bersifat berat adalah mengenai permasalahan Lahan (Agraria) yang membutuhkan pembuktian kompleks serta memakan waktu yang sangat lama. Adanya identifikasi laporan selain bertujuan agar laporan diselesaikan sesuai dengan kemampuan atau kompetensi Asisten juga bertujuan agar terwujudnya efektivitas waktu dalam penyelesaian laporan.

4) Ketidakpastian Hukum

Persoalan ketidakpastian hukum masih menjadi hambatan bagi Ombudsman Perwakilan Kepulauan Riau dalam kegiatan penyelesaian laporan maladministrasi oleh masyarakat. Hal ini terjadi karena peraturan perundangundangan serta peraturan Ombudsman tidak konsisten dan tidak jelas.

Beberapa aturan yang tidak konsisten dan tidak jelas dapat dilihat dari tidak konsistennya Ombudsman mengenai aturan jangka waktu dan atau batas waktu penyelesaian laporan. Permasalahan berikutnya ialah tidak jelasnya pengertian berikut tidak adanya petunjuk teknis mengenai beberapa aturan seperti mengenai Respon Cepat Ombudsman, Tidakan Korektif, dan Pedoman Pelaksanaan Mediasi atau Konsiliasi.

Dalam hal jangka waktu, Peraturan Ombudsman tidak mengatur terkait jangka waktu dalam verifikasi materiil, permintaan data/informasi, mediasi dan konsiliasi. Apabila jangka waktu diatur secara jelas dan tegas, maka otomatis dapat diatur mengenai batasan waktu dalam penyelesaian laporan sehingga tidak terjadi penyelesaian laporan yang berlarut yang bahkan memakan waktu menahun.

Selanjutnya, dalam hal Respon Cepat Ombudsman (RCO) dibutuhkan kejelasan mengenai kriteria laporan tentang apa dan seperti apa sebenarnya makna dari kondisi darurat serta bagaimana mekanisme atau alur penyelesaian dan jangka waktu yang jelas tentang penyelesaian dengan sistem RCO. Hal ini juga berlaku untuk tindakan korektif yang hanya disebutkan dalam peraturan Ombudsman yang tidak dijelaskan seperti apa pengertian serta jenis dari tindakan korektif tersebut berikut jangka waktunya. Terakhir yang tidak kalah penting adalah aturan yang jelas mengenai pedoman pelaksanaan Mediasi dan Konsiliasi oleh Unit Resolusi dan Monitoring.

\section{b. Faktor Eksternal}

1) Kurangnya Dukungan Penyelenggara Pelayanan Publik

Dalam hal ini terdapat beberapa permasalahan, seperti: Pertama, masih kurang pahamnya Penyelenggara 
Pelayanan Publik terhadap kewenangan Ombudsman dalam mengawasi mereka.

Kedua, kurangnya Pengawas Internal atau Aparat Pengawas Internal Pemerintah (APIP) yaitu Inspektorat dalam melaksanakan fungsinya.

Ketiga, belum semua Kantor Penyelenggara Pelayanan Publik menyediakan pos penerimaan dan penyelesaian pengaduan.

Keempat, adanya ketentuan lain yang mengatur di sejumlah instansi vertikal bahwa yang berhak memberikan klarifikasi ialah Kantor Pusat.

Kelima, yaitu masih kurangnya dukungan Pimpinan Instansi Terlapor sehingga laporan dilempar kesana-sini dan menyebabkan lambatnya penyelesaian laporan. Bahkan terkadang dalam hal ini yang memberikan klarifikasi atau jawaban bukan merupakan pihak yang berwenang.

2) Kurangnya Koordinasi dan

Kerjasama Ombudsman dengan

Penyelenggara Pelayanan Publik

Salah satu tugas Ombudsman menurut UUORI adalah membangun kordinasi dan kerjasama serta jaringan kerja dengan Lembaga atau Badan Penyelenggara Negara demi keefektifan tugas pengawasan. Namun di Kota Batam sendiri, adanya kerjasama hanya masih dilakukan dengan BP Batam. Ombudsman belum mengadakan kerjasama lain dengan Lembaga atau Badan Penyelenggara lainnya di Kota Batam. Padahal hal ini sangat penting khususnya agar penyelesaian laporan dapat berjalan efektif dan efisien.

3) Kurangnya Kesadaran Masyarakat

Berdasarkan hasil wawancara peneliti dengan Kepala Perwakilan Ombudsman RI Provinsi Kepulauan Riau, dikatakan bahwa belum sadarnya masyarakat untuk menjadikan Ombudsman sebagai lembaga pengaduan pelayanan publik menjadi salah satu faktor pemasalahan eksternal yang menghambat Ombudsman dalam melaksanakan kewenangannya sebagai lembaga pengawas pelayanan publik. Hal ini kemudian dibuktian melalui data Kuesioner dan Wawancara dengan masyarakat bahwa hampir seluruh masyarakat tidak melapor dan atau memilih untuk tidak melaporkan apabila mendapatkan pelanggaran pelayanan publik atau yang biasa disebut dengan maladministrasi.

\section{Efektivitas Peran Ombudsman Republik Indonesia Perwakilan Provinsi Kepulauan Riau sebagai Lembaga Pengawas Pelayanan Publik di Kota Batam}

Dalam hal menilai keefektifan peran Ombudsman, maka peneliti menggunakan Teori Efektivitas Hukum oleh Soerjono Soekanto dan dikaitkan dengan hasil penelitian maka terdapat hasil sebagai berikut:

\section{a. Faktor Hukum}

Dari segi faktor hukum, permasalahan muncul dikarenakan keterbatasan kemampuan hukum terhadap pengaturan Ombudsman RI baik yang terdapat dalam UUORI maupun UUPP 
Winsherly Tan: Efektifitas Peran Ombudsman Republik Indonesia Perwakilan...

serta peraturan pelaksana lainnya. Beberapa permasalahan tersebut, yakni: Pertama, Rekomendasi dan ataupun surat-surat Ombudsman RI bersifat nonlegally Binding (tidak mengikat) terhadap institusi terkait. Dengan maksud lain, Penyelenggara Pelayanan Publik yang memperoleh surat, rekomendasi maupun permintaan klarifikasi oleh Ombudsman RI tidak mempunyai kewajiban hukum guna menindaklanjutinya.

Permasalahan hukum Kedua yang muncul selanjutnya adalah mengenai tidak adanya kejelasan peraturan hukum mengenai apa yang dimaksud serta batas waktu dalam pelaksanaan Tindakan Korektif Ombudsman RI Perwakilan di daerah dalam menyelesaikan laporan maladministrasi. Dikarenakan rekomendasi hanya dapat dikeluarkan oleh Kelompok Keasistenan Inisiatif Strategis yang berkedudukan di Ombudsman Pusat, dalam menyelesaikan laporan, Ombudsman yang berorientasi pada penyelesaian laporan maladministrasi secara persuasif di tingkat perwakilan di daerah dengan cara tindakan korektif yang diatur dalam PO 26/2017. Dalam Peraturan tersebut, tepatnya di dalam pasal 25 (2) huruf f tidak tertera penjelasan mengenai hal yang dimaksud dengan tindakan korektif.

Namun berdasar pada pengamatan dan hasil wawancara peneliti dengan Kepala Pewakilan Ombudsman RI Kepulauan Riau, diketahui bahwa tindakan korektif atau biasa disebut saran koreksian merupakan hal-hal yang harus dilaksanakan dan atau ditindaklanjuti
Terlapor apabila terbukti melakukan maladministrasi.

Selain itu, melalui hasil wawancara diketahui bahwa apabila tindakan korektif tidak dilaksanakan oleh terlapor, maka Ombudsman RI Perwakilan Provinsi Kepulauan Riau akan melakukan monitoring sampai Terlapor mau melaksanakan tindakan korektif tersebut. Misalnya apabila dalam sebuah kasus Ombudsman memberikan waktu pelasanaan saran koreksian selama 30 hari, apabila dalam 30 hari saran koreksian tersebut tidak dilaksanakan oleh Terlapor, maka Ombudsman akan memberikan tambahan waktu kepada Terlapor untuk melaksanakan tindakan korektif tersebut dalam artian menunggu hingga terlapor mau melaksanakan tindakan korektif tersebut. Hal ini tentu akan mengurangi efisiensi Ombudsman dalam menyelesaikan laporan maladministrasi oleh Terlapor.

Permasalahan Ketiga, yakni Peraturan Ombudsman RI tidak mengatur secara tegas mengenai batasan waktu dalam setiap tahapan alur penyelesaian laporan. Di dalam PO 26/2017, dikenal dua jenis mekanisme penyelesaian laporan maladministrasi oleh masyarakat yakni, penyelesaian laporan biasa dan penyelesaian laporan melalui apa yang disebut dengan Respon Cepat Ombudsman atau yang biasa dimaksudkan dengan RCO.

Dalam penyelesaian laporan biasa, undang-undang serta peraturan Ombudsman RI hanya mengatur mengenai jangka waktu dan atau batas 
waktu dalam melengkapi persyaratan formil laporan (maksimal 30 hari), klarifikasi (maksimal 28 hari), pemanggilan (maksimal 42 hari), pemeriksaan lapangan (maksimal 10 hari), putusan pelaksanaan mediasi (maksimal 7 hari), pelaksanaan rekomendasi (maksimal 60 hari), serta monitoring (maksimal 30 hari). Sedangkan dalam hal Pemeriksaan Dokumen, Permintaan Data atau Informasi, konsiliasi, penyusunan LAHP, tindakan korektif, mediasi, monitoring mediasi, ajudikasi tidak dijelaskan berapa lama jangka waktu penyelesaiannya.

Serupa dengan sistem penyelesaian laporan biasa, penyelesaian laporan melalui RCO juga tidak diatur mengenai jangka dan atau batasan waktu dalam mekanisme penyelesaiannya. Lebih parah dikarenakan aturan Ombudsman juga tidak mengatur detail mengenai apa dan bagaimana proses sebenarnya dalam pelaksanaan RCO tersebut.

Tidak terdapatnya peraturan pasti mengenai jangka waktu maupun batasan waktu dalam hal penyelesaian laporan maladministrasi baik penyelesaian laporan biasa maupun RCO mengakibatkan tidak adanya kepastian hukum Ombudsman RI dalam menyelesaikan laporan masyarakat sehingga berpotensi menimbulkan kerugian yang lebih besar bagi Pelapor. Hal ini juga bertentangan dengan asas peyelenggaraan pelayanan publik yang terdapat dalam UUPP, yakni Asas Kepastian Hukum yang berarti Pelaksanaan pelayanan publik diselesaikan dalam kurun waktu yang telah ditentukan yang sudah digariskan oleh aturan hukum.

\section{b. Faktor Penegakan Hukum}

Permasalahan-permasalahan yang dialami Ombudsman dalam melaksanakan tugasnya, yakni Pertama, Ombudsman belum dikenali oleh Penyelenggara Pelayanan Publik terkait dengan kewenangan Ombudsman dalam mengawasi mereka. Akibatnya Penyelenggara Pelayanan Publik sering bersikap tidak kooperatif ketika diawasi.

Dari segi permasalahan tersebut di atas, faktor penyebab terhambatnya Ombudsman Kepulauan Riau dalam menjalankan tugas dan fungsinya adalah dikarenakan kurangnya sosialisasi oleh Ombudsman kepada Penyelenggara Pelayanan Publik. Belum dikenalinya Ombudsman oleh Penyelenggara Pelayanan Publik kemudian menghambat Ombudsman guna melaksanakan kewenangan dan tanggungjawabnya sesuai dengan aturan hukum.

Kedua, kurangnya jumlah personil keasistenan Ombudsman di Provinsi Kepulauan Riau. Dalam menjalankan tugasnya diperwakilan, Ombudsman Kepri hanya memiliki 8 (delapan) Asisten yang bertugas dalam penyelesaian laporan dan pencegahan.

$\begin{array}{ccr}\text { Ketiga, } & \text { permasalahan yang } \\ \text { menghambat } & \text { Ombudsman dalam }\end{array}$ menjalankan tugas dan fungsinya ialah kurangnya dukungan anggaran oleh Pemerintah. Akibatnya, tugas 
Winsherly Tan: Efektifitas Peran Ombudsman Republik Indonesia Perwakilan...

Ombudsman dalam penyelesaian laporan serta upaya pencegahan terhambat.

Agar tugas pengawasan optimal, Ombudsman tentu membutuhkan biaya yang cukup. Contohnya dalam melakukan sosialisasi, Ombudsman memerlukan biaya untuk berbagai keperluan seperti transportasi, penginapan apabila dilaksanakan di luar wilayah kantor perwakilan, swa gedung atau tempat pelaksanaan acara, serta hal ringan yang tak boleh dilupakan misalnya pengadaan konsumsi, brosur, stiker maupun atribut lainnya demi kelancaran acara. Kurangnya biaya tentu menghambat proses sosialisasi tersebut.

Keempat, yakni terhambatnya kinerja Ombudsman Perwakilan akibat Memorandum Ombudsman Pusat yang harus dilaksanakan. Di samping tugas penyelesaian laporan dan upaya pencegahan di wilayah Provinsi, Ombudsman Perwakilan juga memiliki kewajiban lain untuk melaksanakan tugastugas sesuai dengan isi Memorandum dari Ombudsman Pusat. Adanya memorandum ini tentu akan menambah pekerjaan dan mengganggu pekerjaan holistik Ombudsman Perwakilan untuk menerima dan menyelesaikan laporan masyarakat.

\section{c. Faktor Sarana atau Fasilitas}

Ombudsman melalui PO 32/2018 mengatur mengenai Standarisasi Sarana dan Prasarana Kantor di Lingkungan Ombudsman RI. Dalam aturan tersebut tertulis bahwa yang dimaksud dengan Sarana adalah "Fasilitas yang secara langsung berfungsi sebagai penunjang proses penyelenggaraan tugas dan fungsi di Lingkungan Ombudsman". Sedangkan Prasarana adalah "Fasilitas yang secara tidak langsung berfungsi sebagai penunjang proses penyelenggaraan tugas dan fungsi di Lingkungan Ombudsman".

Standar sarana dan fasilitas pada kantor perwakilan Ombudsman sebagaimana diatur dalam $\mathrm{Bab}$ IV PO 32/2018 terdiri dari 2 (dua), yakni: Standar dan Prasarana Kantor serta Standar dan Prasarana Lahan dan Bangunan. Standar dan Prasarana Kantor sendiri terdiri dari Ruang Kantor, Ruang Penunjang, Perlengkapan Kantor dan Kendaraan Dinas Operasional Kantor.

Ruang Kantor sebagaimana diatur dalam pasal 11 PO 32/2018 terdiri dari Ruang Kepala Perwakilan, Ruang Bendahara serta Ruang Fungsional Umum dan Asisten. Sedangkan Ruang Penunjang diatur dalam pasal 12 yang terdiri dari Ruang Rapat Besar, Ruang Rapat, Ruaang Fasilitas Pengaduan Masyarakat, Musala, Ruang Laktasi, Ruang Tunggu, Ruang Arsip, Toilet, Ruang Lobi, Ruang Penyimpanan Barang, Ruang Dapur (Pantry) serta Ruang Merokok.

Selanjutnya mengenai Perlengkapan Ruang Kantor, Perlengkapan Ruang Penunjang, Kendaraan Dinas Operasional Kantor, serta penjelasan Lahan dan Bangunan diatur lebih lengkap masingmasing dalam Lampiran IV, Lamoiran V, Lampiran VI, serta Lampiran VII. Berdasarkan aturan yang telah disebutkan, terdapat beberapa ketidaksesuaian fasilitas dan sarana yang terdapat di 
Kantor Ombudsman RI Perwakilan Provinsi Kepri.

Ketidaksesuaian tersebut yakni Pertama, dari segi Ruang Kantor tepatnya Ruang Kepala Perwakilan hanya dilengkapi dengan Ruang Kerja dari yang seharusnya dilengkapi pula dengan Ruang Tamu, Ruang Rapat, Ruang Istirahat berikut dengan Ruang Toilet khusus yang disertai dengan perlengkapannya. Sedangkan Ruang Sekretarian dan Bendahara, serta Ruang Asisten Ombudsman sudah memenuhi fasilitas yang dibutuhkan namun dengan ukuran ruang yang tidak memadai atau sempit.

Kedua, dari segi Ruang Penunjang, dari 12 (dua belas) sarana Ombudsman Kepri hanya menyediakan 6 (enam) sarana saja yakni Ruang Rapat, Ruang Pengaduan, Ruang Tunggu, Ruang Arsip, Ruang Lobi dan Ruang Dapur. Sisanya yang tidak terdapat dalam Kantor Ombudsman Kepri yakni Ruang Rapat Besar, Musala, Ruang Laktasi, Toilet, Ruang Penyimpanan Barang dan Ruang Merokok.

Permasalahan lainnya tidak sesuainya sarana yang ada dengan yang tertera dalam aturan seperti halnya Ruang Rapat yang hanya berkapasitas 10 (sepuluh) orang padahal seharusnya 30 (tiga puluh) orang, Ruang Pengaduan yang sempit dan hanya berkapasitas 4 (empat) orang, Ruang Tunggu yang hanya berkapasitas 6 (enam) orang serta Ruang Dapur yang sempit dan dijadikan pula sebagai Ruang Penyimpanan Barang. Sedangkan Permasalahan bagi Sarana yang tidak ada di dalam Kantor Ombudsman sendiri seperti Ruang Rapat Besar menyewa Ruang Rapat Gedung Graha Pena apabila diperlukan Rapat besar ataupun menyewa Ruangan Hotel berikut Musala dan Toilet yang menggunakan fasilitas Gedung Graha Pena.

Ketiga, Mobil merupakan satusatunya Kendaraan Dinas yang dimiliki Ombudsman Kepri dari 3 (tiga) kendaraan dinas yang diharuskan oleh PO 32/2018. Serta Keempat, Kantor yang tidak berdiri sendiri melainkan terdapat di dalam Gedung bersama yang otomatis menyulitkan Ombudsman Kepri untuk melengkapi kebutuhan sarana dan fasilitas kantor semestinya.

\section{d. Faktor Masyarakat dan Budaya}

Dalam hal menganalisa faktor masyarakat dan budaya, Peneliti menggunakan hasil kuesioner sebagai rujukan. Kuesioner tersebut Peneliti sebarkan ke seluruh kecamatan di Kota Batam dengan total sebanyak 158 (seratus lima puluh delapan) responden, dengan hasil grafik sebagai berikut: 
Winsherly Tan: Efektifitas Peran Ombudsman Republik Indonesia Perwakilan...

\section{Gambar 2. Hasil Grafik Jumlah Usia Responden}

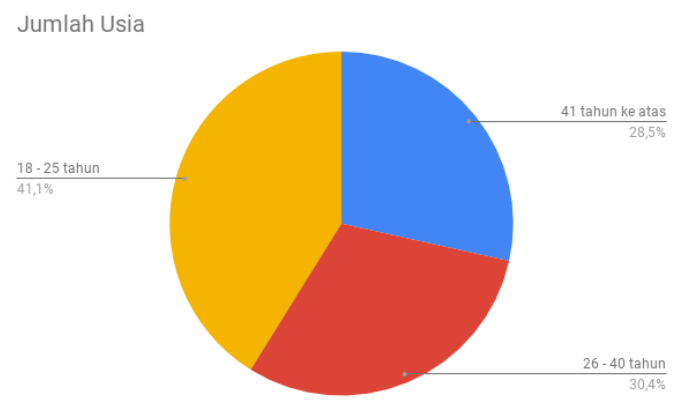

Sebelum memasuki pertanyaan mengenai substansi penelitian, dalam kuesioner Peneliti memberikan pertanyaan rentang usia Responden yakni peneliti memberikan 3 (tiga) opsi pilihan usia bagi Responden diantaranya: 18-25 tahun, 26-40 tahun, dan 41 tahun ke atas. Melalui hasil kuesioner dan grafik di atas, diperoleh hasil bahwa Responden didominasi oleh masyarakat dengan rentang usia 18-25 tahun.

\section{Gambar 3. Hasil Grafik Jenis Pekerjaan Responden}

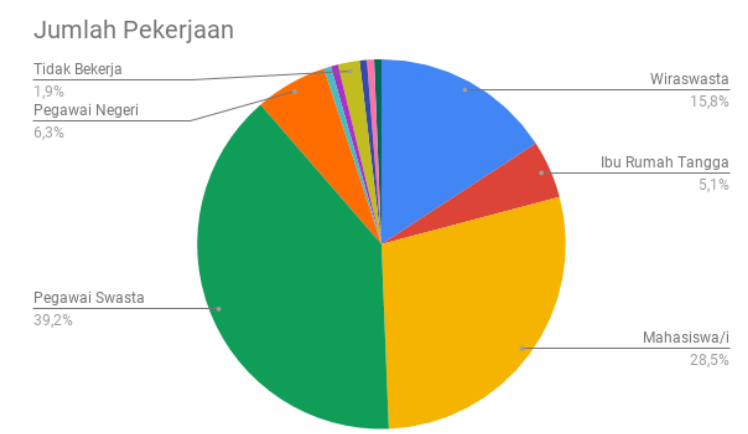

Berikutnya melalui hasil grafik Tangga dan bahkan tidak bekerja. kuesioner di atas dapat diketahui bahwa Berdasarkan opsi tersebut, melalui grafik Peneliti memberikan pilihan opsi kepada di atas dapat diketahui bahwa responden responden untuk pekerjaannya, yakni: terbanyak merupakan Pegawai swasta Pegawai Negeri, Pegawai Swasta, dengan total sebanyak 39,2\% responden. Wiraswasta, Mahasiswa/i, Ibu Rumah

\section{Gambar 4. Hasil Grafik Alamat Responden}

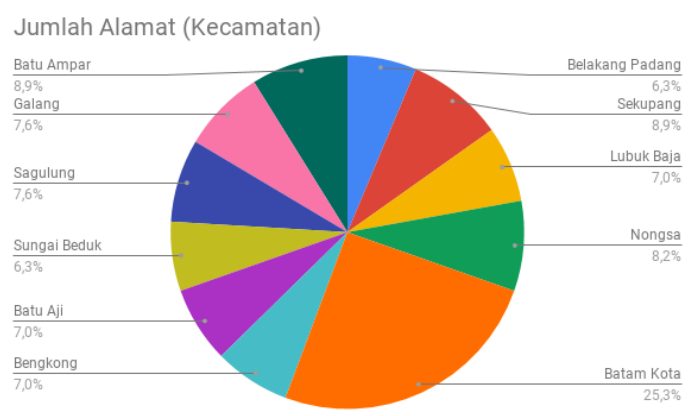

Selanjutnya, melalui Hasil Grafik di menyebarkan kuesioner ke seluruh atas dapat diketahui bahwa Peneliti wilayah Kota Batam dengan Responden 
terbanyak berasal dari Kecamatan Batam Kota dengan total 25,3 Responden. Dari 12 (dua belas) kecamatan di Kota Batam, Peneliti tidak menyebarkan kuesioner di wilayah Bulang dikarenakan keterbatasan Peneliti dalam mengakses lokasi tersebut. Di dalam faktor masyarakat dan budaya, permasalahan yang Peneliti temui yakni masih banyaknya masyarakat Kota Batam yang belum mengenai apa itu Ombudsman berikut pengertian maladministrasi. Hal ini dibuktikan berdasarkan Kuesioner yang Peneliti sebarkan di seluruh Kecamatan di Kota Batam dalam rentang waktu Desember 2018 - Mei 2019 dengan total 158 Responden yang menunjukkan hasil sebagai berikut:

\section{Gambar 5. Grafik Kenal atau Tidaknya Responden kepada Ombudsman}

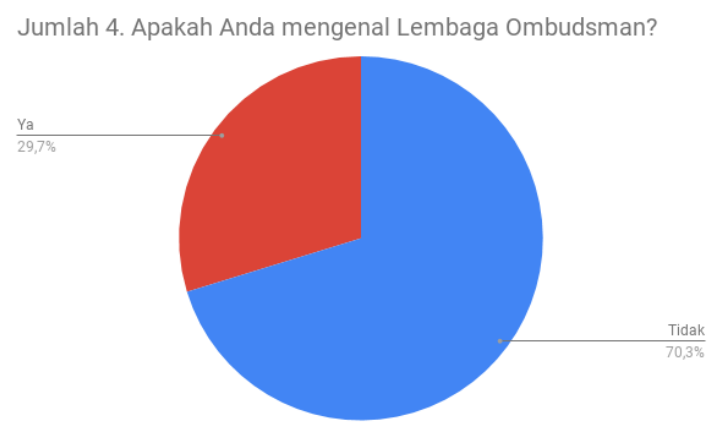

Melalui hasil grafik di atas dapat disimpulkan bahwa masih banyak sekali masyarakat di Kota Batam yang mengaku tidak mengenal Ombudsman sebagai Lembaga Pengawas Pelayanan Publik. Hal ini terbukti dari hanya sebesar 29,7\% dari total keseluruhan Responden atau hanya sebanyak 47 Responden yang mengaku mengenal Lembaga Ombudsman.Sisanya yakni sebesar 70,3\% atau sebanyak 111 orang tidak memahami atau bahkan tidak pernah melihat ataupun mendengar tentang Ombudsman.

Banyaknya jumlah Responden yang tidak mengenal Ombudsman ternyata tidak sejalan dengan penyelenggaraan pelayanan publik yang baik di Kota Batam dimana hal tesebut dapat dibuktikan melalui hasil grafik berikut ini:

\section{Gambar 6. Hasil Grafik pengalaman maladministrasi oleh masyarakat}

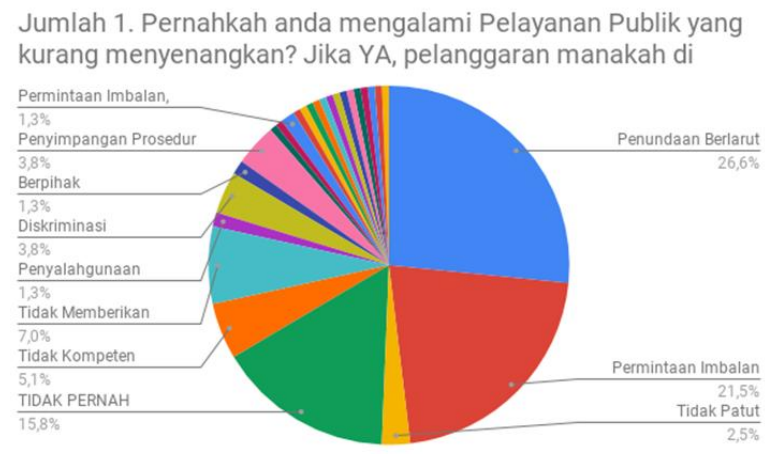

Berdasarkan hasil grafik di atas dapat diketahui bahwa hampir seluruh
Responden pernah mengalami pelayanan publik yang tidak baik atau maladministrasi di Kota Batam. Jenis 
Winsherly Tan: Efektifitas Peran Ombudsman Republik Indonesia Perwakilan...

maladministrasi terbanyak yang pernah dialami oleh Responden adalah Penundaan berlarut yakni sebesar 26,6\%,

Permintaan Imbalan yakni sebesar 21,5\%, berikut Tidak Memberikan Pelayanan sebanyak $7,0 \%$.

\section{Gambar 7. Hasil Grafik Instansi Terduga Maladministrasi}

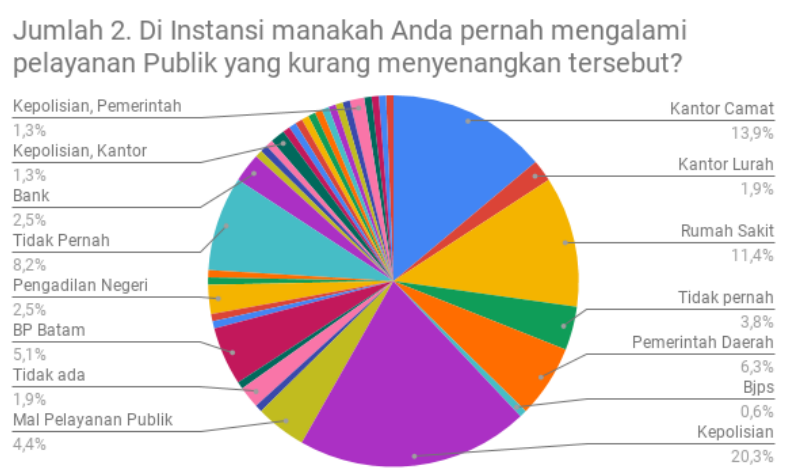

Berdasarkan hasil data di atas dapat

$(4,4 \%)$, Pengadilan Negeri $(2,5 \%)$, Bank diketahui bahwa Instansi tempat $(2,5 \%)$, Kantor Lurah (1,9\%), BPJS masyarakat mengalami maladministrasi bermacam-macam, yakni: Kepolisian $(23,3 \%)$, Kantor Camat (13,9\%), Rumah Sakit (11,4\%), Pemerintah Daerah (6,3\%), $(0,6 \%)$. Hanya sedikit dari masyarakat yang mengaku belum pernah mengalami pelayanan publik yang tidak baik atau maladministrasi.

BP Batam (5,1\%), Mal Pelayanan Publik

\section{Gambar 8. Hasil Grafik melapor atau tidaknya masyarakat terhadap adanya maladministrasi oleh Pelayan Publik}

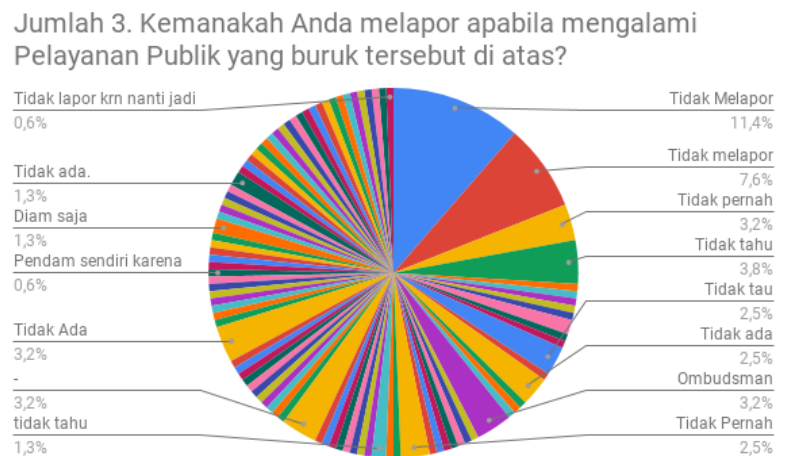

Selanjutnya, Berdasarkan data di atas ternyata hanya $3,2 \%$ Responden yang mangatakan melaporkan maladministrasi tersebut ke Ombudsman Kepulauan Riau sedangkan sisanya menjawab tidak melapor dan diam berikut tidak tahu harus melaporkan ke mana. Hasil kuesioner beserta wawancara ini tentu menjadi permasalahan dalam masyarakat dan budaya yang menghambat efektivitas kinerja Ombudsman dalam mengawasi Pelayanan Publik di Kota Batam.

\section{SIMPULAN}

Pengawasan Lembaga Ombudsman Republik Indonesia Perwakilan Provinsi Kepulauan Riau belum berjalan efektif di Kota Batam. Hal ini dibuktikan melalui 5 (lima) faktor efektivitas hukum oleh teori Soerjono Soekanto yang dihubungkan 
dengan hasil analisa dan fakta dilapangan. Kemudian, faktor penghambatnya yaitu berasal dari internal dan eksternal juga seperti kurangnya SDM di Lembaga Ombudsman Republik Indonesia Perwakilan Provinsi Kepulauan Riau, kurangnya anggaran dan kepastian hukum.

\section{UCAPAN TERIMAKASIH}

Salam hormat dan ucapan terima kasih kami sampaikan kepada Universitas Internasional Batam yang telah mendanai kami dalam melaksanakan penelitian ini dan kami juga mengucapkan terima kasih kepada rekan-rekan akademisi Fakultas Hukum Universitas Internasional Batam yang telah mendukung kami dalam proses penelitian ini, serta Emillia Dwi Setiawati Sianipar sebagai mahasiswa dari Fakultas Hukum Universitas Internasional Batam yang telah banyak membantu dalam pengumpulan data dalam penelitian ini.

\section{DAFTAR KEPUSTAKAAN}

\section{Buku dan Jurnal}

Achmad, Mukti Fajar dan Yulianto. Dualisme Penelitian Hukum. Normatif Dan Empiris. Yogyakarta: Pustaka Pelajar, 2010.

Admin. "Ombudsman Kepri Jangan Jadi Pengumpul Kasus Pelayanan Publik" https://solusihukum.com/ombudsma n-kepri-jangan-jadi-pengumpulkasus-pelayanan-publik/,.

Azhari, Aidul Fitriciada. "Negara Hukum Indonesia: Dekolonisasi Dan Rekonstruksi Tradisi." Jurnal Hukum Ius Quia Iustum 19, no. 4 (2012): 489-505.
Fachrudin, Fachri. "Masyarakat Belum Paham Maladministrasi Bisa Dilaporkan Ke Ombudsman" (2018).

https://nasional.kompas.com/read/2

017/06/19/13113131/masyarakat.bel um.paham.maladministrasi.bisa.dila porkan.ke.ombudsman.

Faqih, Fikri. "Banyak Masyarakat Dinilai

Belum Paham Apa Itu Ombudsman" (2018). https://www.merdeka.com/peristiwa /banyak-masyarakat-dinilai-belumpaham-apa-itu-ombudsman.html.

Hakim, Adhar. "Fungsi Dan Peran Ombudsman Republik Indonesia Perwakilan Nusa Tenggara Barat Dalam Mendorong Kepatuhan Pemerintah Daerah Terhadap Undang-Undang Nomor 25 Tahun 2009 Tentang Pelayanan Publik." Jurnal IUS, Volume III No. 7 (2015).

Holle, Erick S. "Pelayanan Publik Melalui Electronic Government: Upaya Meminimalisir Praktek Maladministrasi Dalam Meningkatan Public Service." Jurnal Sasi Vol.17 No.3 (2011).

Jun. "Pak Gubernur, Kepri Masuk Zona Merah" (2018). https://batampos.co.id/2018/02/22/p ak-gubernur-kepri-masuk-zonamerah/,.

Khozin, Muhammad, Gerry Katon Mahendra, and Anike Febriyani Nugraha. "Pendahuluan UndangUndang Nomor 25 Tahun 2009 Tentang Pelayanan Publik Mengamanahkan Negara Waajib Memberikan Pelayanan Kepada 
Winsherly Tan: Efektifitas Peran Ombudsman Republik Indonesia Perwakilan...

Setiap Warga Negara Dalam Rangka Memenuhi Hak-Hak Dan Kebutuhan Dasarnya Dalam Kerangka Pelayanan Publik . Pemerintah Daerah Seb" 08, no. 2 (2020): 239-256.

Kurniawan, Robi Cahyadi. "Tantangan Kualitas Pelayanan Publik Pada Pemerintah Daerah.” Jurnal Ilmiah Administrasi Publik dan Pembangunan, Vol. 7 No. 1 (2016): 15.

https://docplayer.info/63652465-

Tantangan-kualitas-pelayananpublik-pada-pemerintahdaerah.html.

Kwartya, Kartika. "Ombudsman Buka Kantor Perwakilan Di Batam" (2018). http://batam.tribunnews.com/2012/0 2/28/ombudsman-buka-kantorperwakilan-di-batam.

Marzuki, Peter Mahmud. Penelitian Hukum. Jakarta: Kencana, 2010.

Messa Haris. "Pengaduan Ke Ombudsman Terbanyak Dari Batam" (2018). https://kepri.antaranews.com/berita/ 46976/pengaduan-ke-ombudsmanterbanyak-dari-batam.

Ni Luh Putu Puspitasari, I Komang Gede Bendesa. "Analisis Kualitas Pelayanan Publik Di Badan Pelayanan Perijinan Terpadu Kabupaten Badung." E-Jurnal Ekonomi dan Bisnis Universitas Udayana 5.1 (2016): 90.

Pratama, M. Hamdani. "Strategi Meningkatkan Kualitas Pelayanan Publik (Studi Deskriptif Tentang Strategi UPTD Pengujian
Kendaraan Bermotor Tandes Kota

Surabaya Dalam Meningkatkan Kualitas Pelayanan Pengujian Kendaraan Bermotor)." Jurnal Kebijakan dan Manajemen Publik, Volume 3 (2015): 90.

Riau, Ombudman Republik Indonesia Perwakilan Provinsi Kepulauan. Bahan Bacaan Peserta Training of Trainer Sahabat Ombudsman Perwakilan Kepulauan Riau Di Kabupaten Karimun (2018).

Rinaldi, Rudi. "Analisis Kualitas Pelayanan Publik", Jurnal Administrasi Publik Vol 1, No. 1" (2012).

Rizki, A. Imron. "Analisis Pelaksanaan Rekomendasi Ombudsman Sebagai Instrumen Pengawas Kebijakan Publik" (2018). http://garuda.ristekbrin.go.id/docum ents/detail/1079928.

Roza, Darmini, Universitas Ekasakti, Sekolah Tinggi, and Ilmu Hukum. "Perundang-Undangan Untuk Mewujudkan Indonesia," no. September (2019): 131-144.

Rukayat, Yayat. "Kualitas Pelayanan Publik Bidang Administrasi Kependudukan Di Kecamatan Pasirjambu." Jurnal Ilmiah Magister Ilmu Administrasi (JIMIA) No.2 Tahun XI (2017): 56.

Solechan. "Memahami Peran Ombudsman Sebagai Badan Pengawas Penyelenggaraan Pelayanan Publik Di Indonesia", Administrative Law and Governance Journal Vol 1 Edisi 2 Mei 2018” (2018). 
https://ejournal2.undip.ac.id/index.p hp/alj/article/view/2757.

Syamsudin, M. Operasionalisasi Penelitian Hukum. Jakarta: PT. Raja Grafindo Persada, 2007.

Thahira, Atika. "Penegakan Hukum Administrasi Lingkungan Hidup Ditinjau Dari Konsep Negara Hukum." JCH (Jurnal Cendekia Hukum) 5, no. 2 (2020): 260.

\section{Peraturan Perundang-Undangan}

Undang-Undang Nomor 25 tahun 2009 tentang Pelayanan Publik

Undang-undang Ombudsman Republik Indonesia, UU No.37 tahun 2008, Ketentuan Umum.

Peraturan Pemerintah Republik Indonesia Nomor 21 Tahun 2011 Tentang
Pembentukan, Susunan, Dan Tata Kerja Perwakilan Ombudsman Republik Indonesia Di Daerah.

\section{Hasil Wawancara}

Hasil Wawancara Peneliti dengan Bapak Lagat Parroha Patar Siadari selaku Kepala Ombudsman RI Perwakilan Provinsi Kepulauan Riau pada 20 Desember 2018.

Hasil Wawancara Peneliti dengan Bapak Lagat Parroha Patar Siadari selaku Kepala Ombudsman RI Perwakilan Provinsi Kepulauan Riau pada 21 Desember 2018.

Hasil Wawancara Peneliti dengan Bapak Lagat Parroha Patar Siadari selaku Kepala Ombudsman RI Perwakilan Provinsi Kepulauan Riau pada 21 Desember 2018. 